DE

M E D I C I N A

T R O P I C A L

$\mathrm{DE}$

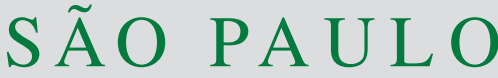

JOURNAL OF THE SÃO PAULO INSTITUTE OF TROPICAL MEDICINE

${ }_{1}^{1}$ Universidade Federal de Mato Grosso, Instituto de Ciências Exatas e Naturais, Curso de Medicina, Rondonópolis, Mato Grosso, Brazil

2Universidade Federal de Mato Grosso, Faculdade de Medicina, Programa de PósGraduação em Ciências da Saúde, Cuiabá, Mato Grosso, Brazil

${ }^{3}$ Secretaria Municipal de Saúde de Rondonópolis, Gerência de Vigilância Epidemiológica, Rondonópolis, Mato Grosso, Brazil

${ }^{4}$ Universidade Federal dos Vales do Jequitinhonha e Mucuri, Faculdade de Medicina do Mucuri, Teófilo Otoni, Minas Gerais, Brazil

${ }^{5}$ Universidade Federal de Mato Grosso, Hospital Júlio Müller, Cuiabá, Mato Grosso, Brazil

Correspondence to: João Gabriel Guimarães Luz

Universidade Federal de Mato Grosso, Instituto de Ciências Exatas e Naturais, Curso de Medicina, Campus Rondonópolis, Av. dos Estudantes, 5055, CEP 78735-901 Rondonópolis, MT, Brazil

E-mail: joaogabrielgl@ hotmail.com

Received: 15 September 2017

Accepted: 4 January 2018

\section{Visceral leishmaniasis in a Brazilian endemic area: an overview of occurrence, HIV coinfection and lethality}

\author{
João Gabriel Guimarães Luz ${ }^{1,2}$, Danilo Bueno Naves ${ }^{1}$, Amanda Gabriela \\ de Carvalho ${ }^{1,2}$, Gilvani Alves Meira ${ }^{3}$, João Victor Leite Dias ${ }^{4}$, Cor Jesus \\ Fernandes Fontes ${ }^{2,5}$
}

\section{ABSTRACT}

The Brazilian municipality of Rondonópolis, Mato Grosso State, represents an important visceral leishmaniasis (VL) endemic area. This study described epidemiological and clinical aspects of the occurrence, VL/HIV coinfection and lethality related to VL in Rondonópolis. Data from autochthonous cases reported between 2011 and 2016 were obtained from official information systems. During this period, 81 autochthonous cases were reported, with decreasing incidence through 2016. Contrastingly, the lethality rate was $8.6 \%$ overall, but varied widely, reaching a peak (20\%) in 2016. Almost $10 \%$ of patients had VL/HIV coinfection. The occurrence of VL prevailed among men (56.8\%), brown-skinned (49.4\%), urban residents $(92.6 \%)$, aged 0-4 years (33.3\%). Housewives or retired (29.6\%) were the most affected occupational groups. Lower age was the main difference among the total VL cases and those who were coinfected or died. Clinically, fever, weakness and splenomegaly were more frequent among all VL cases and VL/HIV coinfected individuals. Bacterial infections $(\mathrm{p}=0.001)$ and bleeding $(\mathrm{p}<0.001)$ were associated with death due to VL. Pentavalent antimonial and liposomal amphotericin B were the first choices for treatment among all VL cases (71.6\%) and those who died (71.4\%), respectively. VL/HIV patients were equally treated with both drugs. These findings may support control measures and demonstrate the need for further investigations.

KEYWORDS: Visceral leishmaniasis. Epidemiology. Lethality. HIV. Coinfection.

\section{INTRODUCTION}

Visceral leishmaniasis (VL), or kala-azar, is a vector-borne zoonotic disease that represents a challenge for Brazilian public health, mainly due to its recent expansion to medium and large urban areas ${ }^{1}$, in addition to high rates of associated mortality ${ }^{2}$. Brazil is among the six countries that comprise $90 \%$ of VL cases worldwide ${ }^{3}$, where approximately 3,500 new cases are reported annually, with an average lethality of $8.1 \%{ }^{2,4}$

Death outcomes in VL are often related to delayed diagnosis ${ }^{5}$, drug toxicity ${ }^{6}$, and inadequate management of patients with signs of unfavorable disease evolution ${ }^{7,8}$. In this regard, age $<5$ and $>40-50$ years, jaundice, thrombocytopenia, bleeding, diarrhea, severe neutropenia, dyspnea, and bacterial infections were recently revised as stronger prognostic factors for death due to $\mathrm{VL}^{7}$. In addition, human immunodeficiency virus (HIV) co-infections deserve attention as a factor commonly associated with VL lethality 9 . In Brazil, the number of individuals with VL/HIV coinfections has been increasing and this population presents three times higher lethality than patients without VL/HIV coinfections ${ }^{10}$. 
Therefore, it is important to evaluate the occurrence of VL in endemic areas, as well as the characteristics among VL/HIV coinfected patients and those who evolved to death due to VL. These contributions are crucial for the development, optimization and conduction of strategies to control the disease and achieve better management of patients $^{9-11}$.

In the past decade, the Brazilian municipality of Rondonópolis has emerged as an important VL endemic area. According to Werneck ${ }^{12}$, from 2001 to 2012, Rondonópolis was among the ten cities responsible for $15.0 \%$ of VL cases reported in Brazil. Despite this great importance, the area lacks studies regarding the disease occurrence. The only report described the spatial distributions of human cases, reservoirs and vectors ${ }^{13}$. Thus, the present study aimed to describe epidemiological and clinical aspects of the occurrence, VL/HIV coinfection and lethality of VL in the municipality of Rondonópolis between 2011 and 2016.

\section{MATERIALS AND METHODS}

\section{Design and study area}

This is a retrospective sectional and descriptive study carried out in Rondonópolis $\left(16^{\circ} 28^{\prime} 15^{\prime \prime} \mathrm{S}\right.$ and $\left.54^{\circ} 38^{\prime} 08^{\prime \prime} \mathrm{W}\right)$, an agricultural and industrial reference center located in the South of Mato Grosso State in Central-Western Brazil. Although the State includes regions of Amazonia and Pantanal, Rondonópolis is located in the Cerrado biome. The municipality has an estimated population of 222,316 inhabitants and a total area of $4,159.12 \mathrm{~km}^{2}$, of which $129.2 \mathrm{~km}^{2}$ are located in the urban area $^{14}$. The actions of the National VL Surveillance and Control Program are currently carried out by public health authorities and are focused on humans, reservoirs and vectors ${ }^{15}$.

\section{Data collection}

Data were obtained by the individual analysis of VL notification/investigation forms and death certificates available from the Brazilian Notifiable Diseases Information and Mortality Information Systems, respectively, which are coordinated by the Epidemiological Surveillance Sector of the Municipal Health Department of Rondonópolis. All autochthonous cases reported and confirmed in the municipality from resident individuals, between 2011 and 2016, were included. Relapses or cases reported in duplicate were excluded. In order to estimate the annual incidence of VL in Rondonópolis, the annual population estimates from the Brazilian Institute of Geography and Statistics were used ${ }^{14}$.

\section{Data analysis}

Data were tabulated and the patients were divided into three groups for the characterization of epidemiological and clinical features: total VL cases (all autochthonous VL cases reported in Rondonópolis), VL/HIV cases (all autochthonous cases of VL/HIV coinfection) and deaths due to VL (all deaths related to VL). It is important to note that the last two groups are contained in the first. Descriptive statistics were used for the analysis in Microsoft ${ }^{\mathrm{TM}}$ Office Excel 2010 (Microsoft Corp., Santa Rosa, CA, USA) and Epi Info ${ }^{\mathrm{TM}}$ version 7.2 (CDC, Atlanta, GA, USA). Fisher's exact tests were performed to verify associations between groups and clinical manifestations and to compare lethality among patients with VL/HIV coinfections and those without. Both analyses were conducted using STATA/SE 11.0 (StataCorp LP, College Station, TX, USA). Differences with a $p$-value $<0.05$ were considered statistically significant.

\section{RESULTS}

During the evaluated period, $117 \mathrm{VL}$ cases were reported in Rondonópolis, of which 81 (69.2\%) were new and autochthonous. The highest incidence of VL was observed in 2011 (12.1/100,000 inhabitants), followed by 2012 (7.9/100,000 inhabitants) and a sharp decline until 2016 (4.6/100,000 inhabitants). In contrast, the overall lethality rate was $8.6 \%$, but varied widely over the years, reaching a peak of $20.0 \%$ in 2016 (Figure 1).

Table 1 summarizes the epidemiological aspects for all autochthonous VL cases reported in Rondonópolis $(\mathrm{n}=81)$,

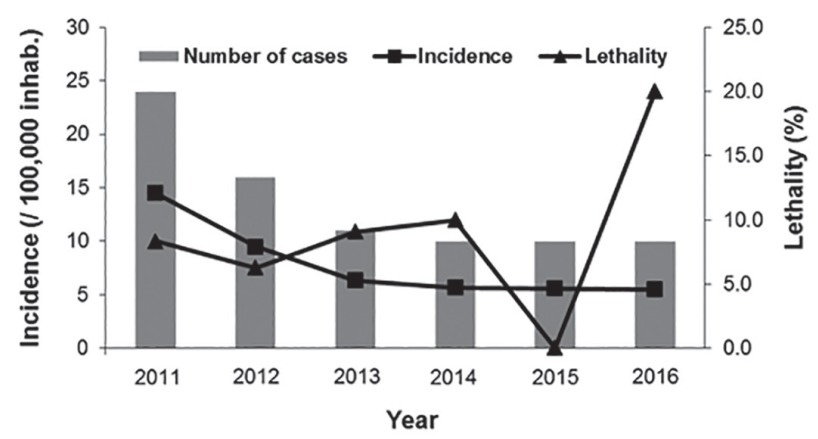

Figure 1 - Number of cases, incidence and lethality rate due to visceral leishmaniasis in the municipality of Rondonópolis, Mato Grosso State, Brazil, between 2011 and 2016. To calculate the incidence, the following population estimates provided by the Brazilian Institute of Geography and Statistics were used: 2011/198,949 inhabitants; 2012/202,309 inhabitants; 2013/208,019 inhabitants; 2014/211,718 inhabitants; 2015/215,320; 2016/218,899 inhabitants 
Table 1 - Epidemiological characteristics related to the total cases of visceral leishmaniasis (total VL cases), VL/HIV coinfection (VL/HIV cases) and lethality due to VL (deaths due to VL) reported in the municipality of Rondonópolis, Mato Grosso State, Brazil, between 2011 and 2016

\begin{tabular}{|c|c|c|c|c|c|c|}
\hline \multirow{3}{*}{ Variable } & \multicolumn{6}{|c|}{ Group } \\
\hline & \multicolumn{2}{|c|}{$\begin{array}{c}\text { Total VL cases } \\
(\mathrm{N}=81)\end{array}$} & \multicolumn{2}{|c|}{$\begin{array}{c}\text { VL/HIV cases } \\
(\mathrm{N}=8)\end{array}$} & \multicolumn{2}{|c|}{$\begin{array}{l}\text { Deaths due to } \mathrm{VL} \\
(\mathrm{N}=7)\end{array}$} \\
\hline & $\mathrm{N}$ & $\%$ & $\mathrm{~N}$ & $\%$ & $\mathrm{~N}$ & $\%$ \\
\hline \multicolumn{7}{|l|}{ Sex } \\
\hline Male & 46 & 56.8 & 6 & 75.0 & 6 & 85.7 \\
\hline Female & 35 & 43.2 & 2 & 25.0 & 1 & 14.3 \\
\hline \multicolumn{7}{|l|}{ Ethnic group } \\
\hline Brown & 40 & 49.4 & 4 & 50.0 & 6 & 85.7 \\
\hline White & 29 & 35.8 & 2 & 25.0 & - & - \\
\hline Black & 10 & 12.3 & 2 & 25.0 & 1 & 14.3 \\
\hline Ignored / blank & 2 & 2.5 & - & - & - & - \\
\hline \multicolumn{7}{|l|}{ Residential area } \\
\hline Urban & 80 & 98.8 & 8 & 100.0 & 7 & 100.0 \\
\hline Rural & 1 & 1.2 & - & - & - & - \\
\hline \multicolumn{7}{|l|}{ Age group (years) } \\
\hline $0-4$ & 27 & 33.3 & - & - & - & - \\
\hline $5-9$ & 4 & 4.9 & - & - & - & - \\
\hline $10-19$ & 3 & 3.7 & - & - & - & - \\
\hline $20-29$ & 8 & 9.9 & 1 & 12.5 & - & - \\
\hline $30-39$ & 16 & 19.8 & 3 & 37.5 & 2 & 28.6 \\
\hline $40-49$ & 11 & 13.6 & 2 & 25.0 & 1 & 14.3 \\
\hline $50-59$ & 5 & 6.2 & 2 & 25.0 & 1 & 14.3 \\
\hline$\geq 60$ & 7 & 8.6 & - & - & 3 & 42.8 \\
\hline \multicolumn{7}{|l|}{ Educational level ${ }^{ \pm}$} \\
\hline Illiterate or primary education (incomplete) & 10 & 18.5 & 3 & 37.5 & 2 & 28.6 \\
\hline Primary education & 17 & 31.5 & 4 & 50.0 & 2 & 28.6 \\
\hline Elementary education & 7 & 13.0 & - & - & 1 & 14.2 \\
\hline Secondary education or higher education & 11 & 20.4 & - & - & - & - \\
\hline Ignored / blank & 9 & 16.6 & 1 & 12.5 & 2 & 28.6 \\
\hline \multicolumn{7}{|l|}{ Occupation ${ }^{ \pm}$} \\
\hline Housewife or retired & 16 & 29.6 & 4 & 50.0 & 3 & 42.8 \\
\hline Unemployed & 7 & 13.0 & 3 & 37.5 & 3 & 42.8 \\
\hline Student & 7 & 13.0 & - & - & - & - \\
\hline Building construction job & 5 & 9.3 & - & - & - & - \\
\hline Self employed & 4 & 7.4 & - & - & - & - \\
\hline Others & 14 & 25.9 & 1 & 12.5 & - & - \\
\hline Ignored / blank & 1 & 1.8 & - & - & 1 & 14.4 \\
\hline \multicolumn{7}{|l|}{ HIV co-infection } \\
\hline Yes & 8 & 9.9 & 8 & 100.0 & 2 & 28.6 \\
\hline No & 66 & 81.5 & - & - & 5 & 71.4 \\
\hline Ignored / blank & 7 & 8.6 & - & - & - & - \\
\hline
\end{tabular}

${ }^{ \pm}$Infants or young children aged $0-4$ years $(\mathrm{N}=27)$ were not included in these variables. 
VL/HIV cases $(n=8)$ and deaths due to VL $(n=7)$. The occurrence of disease prevailed among men $(56.8 \%)$, brown-skinned individuals (49.4\%) from the urban area of the municipality (92.6\%). Although the median patient age was 31.1 years (range 0.3 to 81.3 years), children 0 to 4 years of age comprised most of the cases (33.3\%), followed by adults 30 to 39 years of age (19.8\%). Excluding children, VL was more frequent among individuals with low educational level. In addition, housewives or retired (29.6\%), unemployed (13.0\%) and students (13.0\%) were the most affected occupational groups.

VL/HIV coinfection was observed in $9.9 \%$ of the autochthonous VL cases, although in $8.6 \%$ of the forms, this field was ignored or not filled. These subjects, as well as those who died due to VL, shared epidemiological similarities, mainly because they were predominantly male (75.0\% and $83.3 \%$, respectively), brown-skinned (50.0\% and $83.3 \%$ ), all urban residents, with low educational level, housewives or retired $(50.0 \%$ and $37.5 \%$ ), and unemployed $(42.8 \%)$. The median patient age in the coinfected and mortality groups were higher, at 39.8 and 55.9 years, respectively, predominantly among those in the range of $30-39(37.5 \%)$ and $\geq 60(50.0 \%)$ years of age, respectively. Excluding patients with unknown HIV infection status, no significant difference was found in lethality related to VL between individuals who were VL/HIV coinfected $(25 \%$, $2 / 8)$ and non-coinfected $(7.6 \%, 5 / 66)(p=0.163)$ (data not shown).

Fever $(95.1 \%)$, weakness $(82.7 \%)$ and splenomegaly (79.0\%) were the most common clinical manifestations among VL cases, although signs of severe disease were frequently observed, including jaundice (33.3\%) and edema (18.5\%). In VL/HIV coinfected patients, there was a high frequency of bacterial infections (37.5\%) and bleeding (25.0\%), in addition to the classical manifestations. As expected, severe and diversified manifestations were observed among those patients who evolved to death due to VL. In this sense, bacterial infections $(85.7 \%)(p=0.001)$ and bleeding $(71.4 \%)(p<0.001)$ were significantly associated with death outcome (Table 2).

Table 2 - Frequency of clinical manifestations among the total cases of visceral leishmaniasis (total VL cases), VL/HIV coinfection (VL/HIV cases) and lethality due to VL (deaths due to VL) reported in the municipality of Rondonópolis, Mato Grosso State, Brazil, between 2011 and 2016

\begin{tabular}{|c|c|c|c|c|c|c|c|c|c|c|c|}
\hline \multirow{3}{*}{ Clinical manifestation } & \multicolumn{11}{|c|}{ Group } \\
\hline & \multicolumn{3}{|c|}{$\begin{array}{l}\text { Total VL cases } \\
\qquad(\mathrm{N}=81)\end{array}$} & \multicolumn{4}{|c|}{$\begin{array}{l}\text { VL/HIV cases } \\
\quad(N=8)\end{array}$} & \multicolumn{4}{|c|}{$\begin{array}{l}\text { Deaths by VL } \\
\qquad(N=7)\end{array}$} \\
\hline & $\mathrm{N}$ & $\%$ & $\mathrm{Cl} 95 \%$ & $\mathrm{~N}$ & $\%$ & Cl $95 \%$ & $p$-value ${ }^{ \pm}$ & $\mathrm{N}$ & $\%$ & Cl $95 \%$ & $p$-value ${ }^{\varphi}$ \\
\hline Fever & 77 & 95.1 & $87.6-98.4$ & 8 & 100.0 & $67.6-100.0$ & 1.000 & 7 & 100.0 & $64.6-100.0$ & 1.000 \\
\hline Weakness & 67 & 82.7 & $73.1-89.4$ & 7 & 87.5 & $52.9-97.8$ & 1.000 & 6 & 85.7 & $48.7-97.4$ & 1.000 \\
\hline Splenomegaly & 64 & 79.0 & $68.9-86.5$ & 7 & 87.5 & $52.9-97.8$ & 0.683 & 7 & 100.0 & $64.6-100.0$ & 0.335 \\
\hline Hepatomegaly & 63 & 77.8 & $67.6-85.5$ & 8 & 100.0 & $67.6-100.0$ & 0.587 & 7 & 100.0 & $64.6-100.0$ & 0.338 \\
\hline Weigh loss & 63 & 77.8 & $67.6-85.5$ & 7 & 87.5 & $52.9-97.8$ & 0.677 & 6 & 85.7 & $48.7-97.4$ & 1.000 \\
\hline Pallor & 62 & 75.3 & $66.3-84.4$ & 6 & 75.0 & $40.9-92.9$ & 0.985 & 6 & 85.7 & $48.7-97.4$ & 0.675 \\
\hline Jaundice & 26 & 32.1 & $22.9-42.9$ & 2 & 25.0 & $7.2-59.1$ & 0.719 & 3 & 42.9 & $15.8-75.0$ & 0.675 \\
\hline Cough and/or diarrhea & 25 & 30.9 & $21.9-41.6$ & 2 & 25.0 & $7.2-59.1$ & 1.000 & 2 & 28.6 & $8.2-64.1$ & 1.000 \\
\hline Bacterial infections & 22 & 27.2 & $18.7-37.7$ & 3 & 37.5 & $13.7-69.4$ & 0.676 & 6 & 85.7 & $48.7-97.4$ & $0.001^{*}$ \\
\hline Edema & 14 & 17.3 & $10.6-27.0$ & 1 & 12.5 & $2.2-47.1$ & 1.000 & 1 & 14.3 & $2.6-51.3$ & 0.597 \\
\hline Blood dyscrasias & 8 & 9.9 & $5.1-18.3$ & - & - & - & - & 1 & 14.3 & $2.6-51.3$ & 0.981 \\
\hline Bleeding & 7 & 8.6 & $4.3-16.8$ & 1 & 12.5 & $2.2-47.1$ & 0.981 & 5 & 71.4 & $35.9-91.8$ & $<0.001^{*}$ \\
\hline Headache & 2 & 2.5 & $0.7-8.6$ & - & - & - & - & - & - & - & - \\
\hline Abdominal distension & 2 & 2.5 & $0.7-8.6$ & - & - & - & - & 1 & 14.3 & $2.6-51.3$ & - \\
\hline Arrhythmia & 1 & 1.2 & $0.2-6.7$ & - & - & - & - & - & - & - & - \\
\hline Itchy face & 1 & 1.2 & $0.2-6.7$ & - & - & - & - & - & - & - & - \\
\hline Kidney and liver failure & 1 & 1.2 & $0.2-6.7$ & - & - & - & - & 1 & 14.3 & $2.6-51.3$ & - \\
\hline Pneumonia & 1 & 1.2 & $0.2-6.7$ & - & - & - & - & 1 & 14.3 & $2.6-51.3$ & - \\
\hline
\end{tabular}

${ }^{ \pm}$Comparison of proportions of clinical manifestations between VL/HIV co-infected and non-co-infected VL patients. ${ }^{\varphi} \mathrm{Comparison}$ of proportions of clinical manifestations between VL patients who evolve to death and VL patients who do not. *Significant at Fisher exact test. 
VL treatment was initially performed mainly with pentavalent antimonial in all cases $(71.6 \%)$, with drug failure and cure reported in $7.4 \%$ and $71.6 \%$ of the patients, respectively. Liposomal amphotericin B was used to treat the majority $(71.4 \%)$ of those who died due to VL, with only one $(14.3 \%)$ drug failure report in this group. For VL/HIV cases, the use frequency of the two drugs was the same (50.0\%). Drug failure and cure were reported in $12.5 \%$ and $62.5 \%$ of these patients, respectively (Table 3 ).

\section{DISCUSSION}

The current expansion of VL in Brazilian territories represents a clinical and epidemiological concern for public health authorities and health professionals, especially due to the complexity associated with its control and clinical management ${ }^{1,4,8}$. The State of Mato Grosso is historically endemic for $\mathrm{VL}^{16}$, with the municipality of Rondonópolis containing almost half of the human cases reported there in recent years, being an area of intense VL transmission with regional and national relevance ${ }^{12,13}$.

In this context, the geographical localization of the municipality is a topic that deserves attention. Rondonópolis is nearby and easily connected by transport routes to the municipality of Campo Grande, State of Mato Grosso do Sul, which previously emerged as a highly endemic area in $2001^{17}$. Going North, Rondonópolis also represents the main path of entrance to the West Amazonian Basin, where some States with no reporting of autochthonous human VL cases, such as Rondônia and Amazonas are located ${ }^{18}$. Considering the possibility of vectors and reservoirs dispersion, as well as the intense demographic flow between these areas, Rondonópolis could contribute to the installation of human VL in these settings ${ }^{18-20}$, as recently proposed by Sevá et al. ${ }^{21}$ in the State of São Paulo, Brazil.

Despite the observed decline in VL over the evaluated years, the incidence of the disease in Rondonópolis was considerable higher than the Brazilian average, which ranged from 1.6 to 2.0 new cases/100,000 inhabitants per year between 2011 and $2015^{22}$. Consequently, the absolute number of reported autochthonous cases also decreased with maintenance of high endemicity levels. This stabilization has also been noted in official data from Brazil between 2011 and $2015^{23}$, and may be related to control measures along with lasting immunity developed in the affected populations, which probably generates herd immunity ${ }^{1}$. However, considering the reemergence potential of VL, these observations should be interpreted with caution, since changes in the natural environment associated with favorable epidemiological conditions may lead to large outbreaks and epidemics ${ }^{24}$.

Table 3 - Treatment aspects and outcomes related to the total cases of visceral leishmaniasis (total VL cases), VL/HIV coinfection (VL/HIV cases) and lethality due to VL (deaths due to VL) reported in the municipality of Rondonópolis, Mato Grosso State, Brazil, between 2011 and 2016

\begin{tabular}{|c|c|c|c|c|c|c|}
\hline \multirow{3}{*}{ Variable } & \multicolumn{6}{|c|}{ Group } \\
\hline & \multicolumn{2}{|c|}{$\begin{array}{l}\text { Total VL cases } \\
\quad(\mathrm{N}=81)\end{array}$} & \multicolumn{2}{|c|}{$\begin{array}{l}\text { VL/HIV cases } \\
\quad(\mathrm{N}=8)\end{array}$} & \multicolumn{2}{|c|}{$\begin{array}{l}\text { Deaths by VL } \\
\quad(N=7)\end{array}$} \\
\hline & $\mathrm{N}$ & $\%$ & $\mathrm{~N}$ & $\%$ & $\mathrm{~N}$ & $\%$ \\
\hline \multicolumn{7}{|l|}{ Initial treatment } \\
\hline Pentavalent antimonial & 58 & 71.6 & 4 & 50.0 & 2 & 28.6 \\
\hline Liposomal amphotericin B & 17 & 21.0 & 4 & 50.0 & 5 & 71.4 \\
\hline Amphotericin B deoxycholate & 3 & 3.7 & - & - & - & - \\
\hline Ignored / blank & 3 & 3.7 & - & - & - & - \\
\hline \multicolumn{7}{|l|}{ Drug failure } \\
\hline Yes & 6 & 7.4 & 1 & 12.5 & 1 & 14.3 \\
\hline No & 71 & 87.7 & 6 & 75.0 & 6 & 85.7 \\
\hline Ignored / blank & 4 & 4.9 & 1 & 12.5 & - & - \\
\hline \multicolumn{7}{|l|}{ Outcome $^{ \pm}$} \\
\hline Cure & $73^{\varphi}$ & 90.2 & 6 & 75.0 & - & - \\
\hline Death by VL & 7 & 8.6 & 2 & 25.0 & 7 & 100.0 \\
\hline Death by others causes & 1 & 1.2 & - & - & - & - \\
\hline
\end{tabular}

${ }^{ \pm}$Information were checked at the Brazilian Mortality Information System. ${ }^{\varphi}$ The HIV infection status of seven of these patients was unknown. 
On the other hand, lethality has been increasing in Rondonópolis, similar to observations in the State of Alagoas $^{25}$ and nationwide ${ }^{26}$. In addition, the overall lethality rate in the present study $(8.6 \%)$ was considerable and similar to the national average $(8.1 \%)^{2}$. Case fatality related to $\mathrm{VL}$ is usually the consequence of incorrect and/or late diagnosis ${ }^{5}$, drug toxicity ${ }^{6}$, delay in the management of patients who are at higher risk of progressing to death ${ }^{7,8}$, presence of comorbidities such as malnutrition, cardiovascular diseases and immunosuppression, which may evolve to progressive and fatal weakness ${ }^{2,7,27}$.

Indeed, in Rondonópolis, a high occurrence of patients with VL/HIV coinfection (9.9\%) was found, a higher percentage than the one recently reported in Brazil, where the overall percentage of coinfection was approximately $8.5 \%$ in $2013^{28}$. This is probably related to the increasing AIDS detection rate that has recently been observed in the municipality ${ }^{29}$, and in other medium and small cities located in North and Central-Western Brazil ${ }^{30,31}$. Thus, this pattern of occurrence of the HIV infection along with the urbanization of VL provided the geographical juxtaposition of both diseases ${ }^{4,30}$. In Rondonópolis, this co-occurrence may have been enhanced because this city is a hub of regional entrenchment with accelerated demographic and socioeconomic flow $^{32}$.

Although the observed case fatality among VL/HIV coinfected patients who were investigated in the present study was statistically similar to the non-coinfected, the absolute rate was higher, as similarly reported for the whole country $^{10}$. The relationship between VL/HIV coinfection and VL lethality is not well elucidated because it is not known whether the severity is due to HIV infection or consequent opportunistic infections ${ }^{33}$. Taken together, these findings reinforce the idea that lethality related to VL is a current major concern and underscore the need for improving the diagnosis and management of patients, including HIV infection screening ${ }^{10,33}$.

Except for age groups, the epidemiological profile of VL in Rondonópolis did not differ substantially among the evaluated groups. Children aged 0 to 4 years were the most affected group among VL cases. This pattern was also described by several studies in Brazil ${ }^{11,34,35}$ and abroad ${ }^{36,37}$ and may be related to the fact that, when compared to adults, children have more contact with animal reservoirs and vectors, they have immature immunity and frequent nutritional deficits ${ }^{38}$.

Surprisingly, there was no record of VL case fatality among children, as detected in other studies $^{33,39}$. This outcome was observed only in adults, especially among the elderly, where immunological decline occurs and comorbidities are more frequent ${ }^{33,39}$. Indeed, VL/HIV coinfection was observed exclusively in adults, which is expected due to the decreasing in HIV incidence among children, mainly due to improvements in the prevention of vertical transmission ${ }^{40}$.

In relation to gender, men were the most affected. Although women are equally susceptible to the disease and fatality, this slight predominance may be related to behavioral differences due to the presence of men in areas at higher risk of phlebotomine sand fly bites ${ }^{35,41}$. Furthermore, Guerra-Silveira and Abad-Franch ${ }^{42}$ demonstrated that the risk of VL is significantly male-biased during the first year of life, puberty, reproductive age and in elderly, corroborating with the high occurrence of the disease in these age groups herein detected. A lower proportion of VL/HIV coinfected women was also described ${ }^{10}$ and corroborates the sex ratio of HIV/AIDS patients in the municipality of Rondonópolis, which was 1.4 cases in men for one case in women, in $2014^{29}$.

The predominance of VL among urban residents is consistent with the expansion of the disease to large cities observed in Brazil since the 1980s, mainly due to demographic, environmental, and sanitary factors ${ }^{2,19}$. In Rondonópolis, this process began in the 2000s and may have been influenced by the disorderly growth of the city, migration waves, accelerated population increase, expansion of agriculture, industrialization and the emergence of spaces with marked intra-urban differences ${ }^{43}$, as detected in other regions of the country ${ }^{19,34,35,38}$.

The higher occurrence and lethality of VL among individuals with low educational level has evidenced the socioeconomic vulnerability usually associated with $\mathrm{VL}^{44}$, showing that a lack of schooling can influence health knowledge and practices focused on prevention ${ }^{45}$. In this context, Borges et al. ${ }^{46}$ demonstrated that increased schooling is a protective factor that reduced the risk of VL by 0.64 -fold in the city of Belo Horizonte, Brazil.

Individuals who supposedly remained longer at home (minors and infants, housewives, retired, unemployed and students) were more affected by the disease. These findings suggest the importance of the intra and peri-domiciliary environments in the VL transmission cycle, where reservoirs and vectors are usually found ${ }^{45,47}$.

The clinical manifestations of VL observed in the present study are concordant with those reported by other studies $^{41,48}$. Fever, weakness, hepatomegaly, weight loss and splenomegaly were frequent among VL cases and comprise the classic clinical features of the disease, generally found at the patients admission ${ }^{49}$. Curiously, anemia and pancytopenia (blood dyscrasias) were not detected at high frequencies, although pallor was often reported. These signals are commonly associated with symptomatic $\mathrm{VL}^{50,51}$ 
and are due to blood loss, erythropoiesis dysfunction, and/or up-regulated destruction of erythrocytes, among other factors ${ }^{41,52}$.

On the contrary, jaundice, bacterial infections, edema and bleeding were often reported, especially among patients who died due to VL. These clinical scenarios are related to $\mathrm{VL}$ progression, poor prognosis $\mathrm{s}^{7,48,53}$ and may indicate a late diagnosis; thus, it is essential that health professionals are aware of these signs, which are easily detected in early health services such as emergency care and basic health units $^{35,48}$.

Among VL/HIV coinfected individuals, the clinical presentations of VL were similar to those found in VL cases. According to Lindoso et al. ${ }^{54}$, this is usually verified in clinical practice, so that unusual manifestations tend to occur among patients with very low CD4+ T-cell counts ${ }^{55}$. Unfortunately, the data in the present study did not allow us to check this relationship by assessing the level of these cells.

Due to its zoonotic nature in Brazil, VL treatment has a limited impact on disease transmission, but is essential for the patient ${ }^{15}$. However, the available arsenal remains scarce, in addition to presenting problems related to acceptance, efficacy, side effects and high $\operatorname{cost}^{6,56}$. Similar to observations by Petrela et al. ${ }^{57}$, pentavalent antimonial was the first-line drug for the treatment of most autochthonous cases in Rondonópolis, with low drug failure. Indeed, meglumine antimoniate at $20 \mathrm{mg} / \mathrm{kg} /$ day for 20-40 days has been the standard treatment for VL in Brazil, with no report of drug resistance and high cure rates ${ }^{15}$. However, due to the risk of adverse effects such as cardiotoxicity, pancreatitis and nephrotoxicity, patients should be monitored or hospitalized during therapy ${ }^{58}$.

In this sense, liposomal amphotericin B is recommended as the first choice for the treatment of VL patients with nephropathies and heart diseases in Brazil, as well as individuals who are over 50 years of age, immunosuppressed and with signs of severe VL disease ${ }^{59}$. The lipid formulation assures the delivery of large drug doses in less time with low toxicity ${ }^{60}$. Taken together, the national recommendations support our observation of the increased use of liposomal amphotericin B among VL/HIV coinfected patients and in those who died in the municipality of Rondonópolis.

The main limitation of the present study was the use of secondary data, which is susceptible to lack of information. Nevertheless, our investigation presents an important epidemiological and clinical overview of the occurrence, VL/HIV coinfection and lethality due to VL in the municipality of Rondonópolis, which represents an important endemic Brazilian area with intense transmission. Thus, these data may be useful to help the planning of integrated public health policies focused on VL prevention, early detection and patients' management. Moreover, the results of this study also demonstrated the need for future and more robust investigations involving humans, reservoirs and vectors in the area.

\section{ETHICAL APPROVAL}

This study was approved by the Ethical Committee for Human Research of Júlio Müller University Hospital (CAAE N ${ }^{\circ}$ 52023215.5.0000.5541).

\section{ACKNOWLEDGMENTS}

The authors are grateful to the Epidemiological Surveillance Sector of the Municipal Health Department of Rondonópolis for support in data collection.

\section{REFERENCES}

1. Costa $\mathrm{CH}$. Characterization and speculations on the urbanization of visceral leishmaniasis in Brazil. Cad Saude Publica. 2008;24:2959-63.

2. Martins-Melo FR, Lima MS, Ramos Jr NA, Alencar CH, Heukelbach J. Mortality and case fatality due to visceral leishmaniasis in Brazil: a nationwide analysis of epidemiology, trends and spatial patterns. PLoS One. 2014;9:e93770.

3. Pigott DM, Bhatt S, Golding N, Duda KA, Battle KE, Brady OJ, et al. Global distribution maps of the leishmaniases. eLife. 2014;3:e2851.

4. Maia-Elkhoury AN, Alves WA, Sousa-Gomes ML, Sena JM, Luna EA. Visceral leishmaniasis in Brazil: trends and challenges. Cad Saude Publica. 2008;24:2941-7.

5. Driemeier M, Oliveira PA, Druzian AF, Brum LF, Pontes ER, Dorval ME, et al. Late diagnosis: a factor associated with death from visceral leishmaniasis in elderly patients. Pathog Glob Health. 2015;109:283-9.

6. Alvarenga DG, Escalda PM, Costa AS, Monreal MT. Leishmaniose visceral: estudo retrospectivo de fatores associados à letalidade. Rev Soc Bras Med Trop. 2010;43:194-7

7. Belo VS, Struchiner CJ, Barbosa DS, Nascimento BW, Horta MA, Silva ES, et al. Risk factors for adverse prognosis and death in American visceral leishmaniasis: a meta-analysis. PLoS Negl Trop Dis. 2014;8:e2982.

8. Costa DL, Rocha RL, Chaves EB, Batista VG, Costa HL, Costa $\mathrm{CH}$. Predicting death from kala-azar: construction, development, and validation of a score set and accompanying software. Rev Soc Bras Med Trop. 2016;49:728-40.

9. Távora LG, Nogueira MB, Gomes ST. Visceral Leishmaniasis/ HIV co-infection in northeast Brazil: evaluation of outcome. Braz J Infect Dis. 2015;19:651-6. 
10. Leite de Sousa-Gomes M, Romero GA, Werneck GL. Visceral leishmaniasis and HIV/AIDS in Brazil: are we aware enough? PLoS Negl Trop Dis. 2017;11:e0005772.

11. Ursine RL, Dias JV, Morais HA, Pires HH. Human and canine visceral leishmaniasis in an emerging focus in Araçuaí, Minas Gerais: spatial distribution and socio-environmental factors. Mem Inst Oswaldo Cruz. 2016;111:505-11.

12. Werneck GL. Visceral leishmaniasis in Brazil: rationale and concerns related to reservoir control. Rev Saude Publica. 2014;48:851-6.

13. Guimarães AGF, Alves GBM, Pessoa AM, Silva Jr N. Spatial analysis of visceral leishmaniasis in the municipality of Rondonópolis, in the Brazilian State of Mato Grosso, from 2003 to 2012: human, canine and vector distribution in areas of disease transmission. Rev Soc Bras Med Trop. 2015;48:291300.

14. Instituto Brasileiro de Geografia e Estatística. Brasil/Mato Grosso/ Rondonópolis. [cited 2018 Jan 04]. Available from: https:// cidades.ibge.gov.br/brasil/mt/rondonopolis/panorama

15. Brasil. Ministério da Saúde. Secretaria de Vigilância em Saúde. Departamento de Vigilância Epidemiológica. Manual de vigilância e controle da Leishmaniose Visceral. Brasília: Ministério da Saúde; 2003. [cited 2018 Jan 04]. Available from: http://bvsms.saude.gov.br/bvs/publicacoes/manual_vigilancia_ controle_leishmaniose_visceral.pdf

16. Mestre GL, Fontes CJ. A expansão da epidemia da leishmaniose visceral no Estado de Mato Grosso, 1998-2005. Rev Soc Bras Med Trop. 2007;40:42-8.

17. Botelho AC, Natal D. Primeira descrição epidemiológica da leishmaniose visceral em Campo Grande, Estado de Mato Grosso do Sul. Rev Soc Bras Med Trop. 2009;42:503-8.

18. Reis LL, Balieiro AA, Fonseca FR, Gonçalves MJ. Changes in the epidemiology of visceral leishmaniasis in Brazil from 2001 to 2014. Rev Soc Bras Med Trop. 2017;50:638-45.

19. Conti RV, Moura Lane VF, Montebello L, Pinto Jr VL. Visceral leishmaniasis epidemiologic evolution in timeframes, based on demographic changes and scientific achievements in Brazil. J Vector Borne Dis. 2016;53:99-104.

20. Brazil RP. The dispersion of Lutzomyia longipalpis in urban areas. Rev Soc Bras Med Trop. 2013;46:263-4.

21. Sevá AD, Mao L, Galvis-Ovallos F, Lima JM, Valle D. Risk analysis and prediction of visceral leishmaniasis dispersion in São Paulo State, Brazil. PLoS Negl Trop Dis. 2017;11:e0005353.

22. Brasil. MinistériodaSaúde. Coeficiente de incidênciadeleishmaniose visceral, por 100.000 habitantes: Brasil, Grandes Regiões e Unidades Federadas: 1990 a 2015. [cited 2018 Jan 04]. Available from: http://portalarquivos.saude.gov.br/images/pdf/2016/ novembro/08/LV-Coeficiente\%20de\%20Incidncia.pdf

23. Brasil. Ministério da Saúde. Casos confirmados de leishmaniose visceral: Brasil, Grandes Regiões e Unidades Federadas:
1990 a 2015. [cited 2018 Jan 04]. Available from: http:// portalarquivos.saude.gov.br/images/pdf/2016/novembro/08/ LV-Casos.pdf

24. Arias JR, Monteiro PS, Zicker F. The reemergence of visceral leishmaniasis in Brazil. Emerg Infect Dis. 1996;2:145-6.

25. Rocha TJ, Silva KK, Oliveira VC, Silveira LJ, Wanderly FS, Calheiros CM. Perfil epidemiológico relacionado aos casos de letalidade por leishmaniose visceral em Alagoas: uma análise entre os anos de 2007 a 2012. Rev Cienc Farm Basica Apl. 2015;36:17-20.

26. Brasil. Ministério da Saúde. Letalidade de leishmaniose visceral: Brasil, Grandes Regiões e Unidades Federadas: 2000 a 2015. [cited 2018 Jan 04]. Available from: http://portalarquivos. saude.gov.br/images/pdf/2016/novembro/08/LV-Letalidade. pdf

27. Madalosso G, Fortaleza CM, Ribeiro AF, Cruz LL, Nogueira PA, Lindoso JA. American visceral leishmaniasis: factors associated with lethality in the State of São Paulo, Brazil. J Trop Med. 2012;2012:281572.

28. Lindoso JA, Cota GF, Cruz AM, Goto H, Maia-Elkhoury AN, Romero GA, et al. Visceral leishmaniasis and HIV coinfection in Latin America. PLoS Negl Trop Dis. 2014;8:e3136.

29. Brasil. Ministério da Saúde. Indicadores e dados básicos do HIV/ AIDS dos municípios brasileiros. [cited 2018 Jan 04]. Available from: http://svs.aids.gov.br/aids/

30. Brasil. Ministério da Saúde. Secretaria de Vigilância em Saúde. Departamento de Vigilância Epidemiológica. Manual de recomendações para diagnóstico, tratamento e acompanhamento de pacientes com a coinfecção LeishmaniaHIV. Brasília: Ministério da Saúde; 2011. [cited 2018 Jan 04]. Available from: http://bvsms.saude.gov.br/bvs/publicacoes/ manual_recomendacoes_pacientes_leishmania.pdf

31. Coutinho JV, Santos FS, Ribeiro RD, Oliveira IB, Dantas VB, Santos AB, et al. Visceral leishmaniasis and leishmaniasisHIV coinfection: comparative study. Rev Soc Bras Med Trop. 2017;50:670-4.

32. Sousa AI, Pinto Jr VL. Análise espacial e temporal dos casos de aids no Brasil em 1996-2011: áreas de risco aumentado ao longo do tempo. Epidemiol Serv Saude. 2016;25:467-76.

33. Costa CH, Werneck GL, Costa DL, Holanda TA, Aguiar GB, Carvalho AS, et al. Is severe visceral leishmaniasis a systemic inflammatory response syndrome? A case control study. Rev Soc Bras Med Trop. 2010;43:386-92.

34. Silva ES, Gontijo CM, Pacheco RS, Fiuza VO, Brazil RP. Visceral leishmaniasis in the Metropolitan Region of Belo Horizonte, State of Minas Gerais, Brazil. Mem Inst Oswaldo Cruz. 2001;96:285-91.

35. Araújo AC, Gonçalves NN, Dantas-Torres F, Ferreira F, Horta MC. Visceral leishmaniasis in Petrolina, State of Pernambuco, Brazil, 2007-2013. Rev Inst Med Trop Sao Paulo. 2016;58:29. 
36. Zhao S, Li Z, Zhou S, Zheng C, Ma H. Epidemiological feature of visceral leishmaniasis in China, 2004-2012. Iran J Public Health. 2015:44:51-9.

37. Mniouil M, Fellah H, Amarir F, Et-Touys A, Bekhti K, Adlaoui $\mathrm{EB}$, et al. Epidemiological characteristics of visceral leishmaniasis in Morocco (1990-2014): an update. Acta Trop. 2017;170:169-77.

38. Oliveira IB, Batista HL, Peluzio JM, Pfrimer IA, Rodrigues FM, Carmo Filho JR. Epidemiological and environmental aspects of visceral leishmaniasis in children under 15 years of age between 2007 and 2012 in the City of Araguaína, State of Tocantins, Brazil. Rev Soc Bras Med Trop. 2014;47:476-82.

39. Queiroz MJ, Alves JG, Correia JB. Visceral leishmaniasis: clinical and epidemiological features of children in an endemic area. J Pediatr (Rio J). 2004;80:141-6.

40. Fettig J, Swaminathan M, Murrill CS, Kaplan JE. Global epidemiology of HIV. Infect Dis Clin North Am. 2014;28:32337.

41. Oliveira JM, Fernandes AC, Dorval ME, Alves TP, Fernandes TD, Oshiro ET, et al. Mortalidade por leishmaniose visceral: aspectos clínicos e laboratoriais. Rev Soc Bras Med Trop. 2010;43:188-93.

42. Guerra-Silveira F, Abad-Franch F. Sex bias in infectious disease epidemiology: patterns and processes. PLoS One. 2013;8:e62390.

43. Luz JGG, Carvalho AG, Marques AP, Marcondes AA, Roma JHF, Castro LS et al. Intestinal parasitic infections and associated risk factors in preschoolers from different urban settings in Central-Western Brazil. Asian Pac J Trop Dis. 2017; 7: 405-10.

44. Alvar J, Yactayo S, Bern C. Leishmaniasis and poverty. Trends Parasitol. 2006;22:552-7.

45. Menezes JA, Luz TC, Sousa FF, Verne RN, Lima FP, Margonari C. Peridomiciliary risk factors and knowledge concerning visceral leishmaniasis in the population of Formiga, Minas Gerais, Brazil. Rev Bras Epidemiol. 2016;19:362-74.

46. Borges BK, Silva JA, Haddad JP, Moreira EC, Magalhães DF, Ribeiro LM, et al. Avaliação do nível de conhecimento e de atitudes preventivas da população sobre a leishmaniose visceral em Belo Horizonte, Minas Gerais, Brasil. Cad Saude Publica. 2008;24:777-84

47. Vianna EN, Morais MH, Almeida AS, Sabroza PC, Reis IA, Dias ES, et al. Abundance of Lutzomyia longipalpis in urban households as risk factor of transmission of visceral leishmaniasis. Mem Inst Oswaldo Cruz. 2016;111:302-10.

48. Coura-Vital W, Araújo VE, Reis IA, Amancio FF, Reis AB, Carneiro M. Prognostic factors and scoring system for death from visceral leishmaniasis: an historical cohort study in Brazil. PLoS Negl Trop Dis. 2014;8:e3374.
49. Nail AM, Imam AM. Visceral leishmaniasis: clinical and demographic features in an African population. Pak J Med Sci. 2013;29:485-9.

50. Braga AS, Toledo Jr AC, Rabello A. Factors of poor prognosis of visceral leishmaniasis among children under 12 years of age. A retrospective monocentric study in Belo Horizonte, State of Minas Gerais, Brazil, 2001-2005. Rev Soc Bras Med Trop. 2013;46:55-9.

51. Sarkari B, Naraki T, Ghatee MA, Abdolahi Khabisi S, Davami MH. Visceral leishmaniasis in Southwestern Iran: a retrospective clinico-hematological analysis of 380 consecutive hospitalized cases (1999-2014). PLoS One. 2016;11:e0150406.

52. Goto Y, Cheng J, Omachi S, Morimoto A. Prevalence, severity, and pathogeneses of anemia in visceral leishmaniasis. Parasitol Res. 2017;116:457-64.

53. Werneck GL, Batista MS, Gomes JR, Costa DL, Costa CH. Prognostic factors for death from visceral leishmaniasis in Teresina, Brazil. Infection. 2003;31:174-7.

54. Lindoso JA, Cunha MA, Queiroz IT, Moreira CH. LeishmaniasisHIV coinfection: current challenges. HIV AIDS (Auckl). 2016;8:147-56.

55. Roiko MS, Schmitt BH, Relich RF, Meyet TL, Zhang S, Davis TE. An unusual presentation of leishmaniasis in a human immunodeficiency virus-positive individual. JMM Case Rep. 2016;3:e05011.

56. Moore EM, Lockwood DN. Treatment of visceral leishmaniasis. J Glob Infect Dis. 2010;2:151-8.

57. Petrela R, Kuneshka L, Foto E, Zavalani F, Gradoni L. Pediatric visceral leishmaniasis in Albania: a retrospective analysis of 1,210 consecutive hospitalized patients (1995-2009). PLoS Negl Trop Dis. 2010;4:e814.

58. Freitas-Junior LH, Chatelain E, Kim HA, Siqueira-Neto JL. Visceral leishmaniasis treatment: what do we have, what do we need and how to deliver it? Int J Parasitol Drugs Drug Resist. 2012;2:11-9.

59. Brasil. Ministério da Saúde. Secretaria de Vigilância em Saúde. Departamento de Vigilância Epidemiológica. Leishmaniose visceral: recomendações clínicas para redução da letalidade. Brasília: Ministério da Saúde; 2011. [cited 2018 Jan 05]. Available from: http://bvsms.saude.gov.br/bvs/publicacoes/ leishmaniose_visceral_reducao_letalidade.pdf

60. Sundar S, Chakravarty J. An update on pharmacotherapy for leishmaniasis. Expert Opin Pharmacother. 2015;16:237-52. 